\title{
Familial paroxysmal ataxia
}

INSERM

\section{Source}

INSERM. (1999). Orphanet: an online rare disease and orphan drug data base. Familial paroxysmal ataxia. ORPHA:97

Episodic ataxia type 2 (EA2) is the most frequent form of Hereditary episodic ataxia (EA; see this term) characterized by paroxysmal episodes of ataxia lasting hours, with interictal nystag mus and mildly progressive ataxia. 